\title{
DEVELOPMENT OF RABBIT EMBRYOS IN VITRO AND IN VIVO FOLLOWING STORAGE OF THE TWO-CELL STAGE AT $10^{\circ} \mathrm{C}$
}

\author{
GARY B. ANDERSON* AND R. H. FOOTE \\ Department of Animal Science, and Division of Biological Sciences, \\ Cornell University, Ithaca, New York 14853, U.S.A.
}

(Received 4th February 1975)

In 1947, Chang successfully stored young rabbit embryos for several days at $10^{\circ} \mathrm{C}$. Recent interest in the practical application of embryo transfer techniques to livestock has resulted in renewed efforts to preserve mammalian embryos by refrigeration (Sreenan et al., 1970; Kardymowicz, 1972; Moore \& Bilton, 1973; Anderson \& Foote, 1975b), and by freezing (Wilmut \& Rowson, 1973; Bank \& Maurer, 1974; Whittingham \& Whitten, 1974).

Anderson \& Foote $(1974,1975 \mathrm{a})$ reported that embryo metabolism is reduced while embryos are held at $10^{\circ} \mathrm{C}$, but substrate utilization and normal DNA, RNA and protein synthesis is restored by rewarming to $37^{\circ} \mathrm{C}$. The experiments reported in this paper were conducted to compare the relative development of embryos in vitro and in vivo following storage at low temperature.

Two-celled embryos from mature Dutch-Belted rabbits induced to superovulate with FSH (Armour) and LH (Armour) (Kennelly \& Foote, 1965) were collected $26 \mathrm{hr}$ after $\mathbf{L H}$ administration, pooled, and randomly distributed to treatment groups. Superovulatory response usually ranged from about 30 to 50 ovulations/doe. Experiment I was a study of the effect of low-temperature storage upon the proportion of embryos which developed into blastocysts in vitro and in vivo. Experiment II compared the degree of trophoblast expansion for blastocysts $120 \mathrm{hr}$ after LH injection under both conditions.

In Exp. I, the embryos in Treatment 1 were cultured for $94 \mathrm{hr}$ in BSM II, the chemically defined medium used in this laboratory for embryo culture at $37^{\circ} \mathrm{C}$ (Kane \& Foote, 1970). In Treatment 2 embryos were cooled to $10^{\circ} \mathrm{C}$ and held for $24 \mathrm{hr}$ in BSM II plus $4 \%$ Promine-D (Anderson \& Foote, 1975b) before rewarming and culturing as in Treatment 1 . In Treatment 3 , from 5 to 15 embryos were transferred to each oviduct of females mated to vasectomized males at the same time as the donor rabbits had been injected with $\mathrm{LH}$ and inseminated. These embryos were flushed from the uteri of the recipient does $94 \mathrm{hr}$ after transfer to study development. In Treatment 4, embryos were first stored as in Treatment 2 and then transferred to synchronized recipients and recovered as in Treatment 3 . The number of embryos examined for Treatments 1 to 4 were 420,551, 299 and 332, respectively. Unequal numbers resulted

* Present address: Department of Animal Science, University of California, Davis, California 95616, U.S.A. 
because of differential development and recovery following transfer and the loss of some cultured embryos due to bacterial contamination.

The four treatments of Exp. I were used in Exp. II, plus Treatment 5, which involved blastocysts collected from the uteri of donor females $120 \mathrm{hr}$ after they were stimulated to superovulate and inseminated. Trophoblast expansion was determined by averaging the measurements of the long and short diameters of all morphologically normal blastocysts at $\times 40$ or $\times 100$ with a micrometer fitted on a light microscope. The total number of blastocysts for Treatments 1 to 5 were $464,209,242,269$, and 462 , respectively.

An analysis of variance for unequal subclasses was used to test for treatment effects in both experiments and Tukey's honest significant difference was used to test for differences among treatment means (Steel \& Torrie, 1960).

The results of Exp. 1 showed that more blastocysts developed in vivo than in vitro (mean \pm S.E. : Treatment $1,60 \pm 4.4 \%$; Treatment 2, $22 \pm 3.0 \%$; Treatment $3,88 \pm 2 \cdot 5 \%$; Treatment $4,66 \pm 5 \cdot 9 \%$ ). All means are different from each other $(P<0.05)$. Storage at $10^{\circ} \mathrm{C}$ for $24 \mathrm{hr}$ reduced the number of embryos forming blastocysts, but the difference between stored and unstored embryos which were transferred to recipients was less than for those cultured in vitro, and the in vitro $\times$ in vivo interaction was significant $(P<0 \cdot 10)$. In other experiments (Anderson \& Foote, 1975b), the difference in development rate between stored and unstored embryos transferred to recipients was similar to that in the present trial, but was not statistically significant with the fewer embryos involved.

In Exp. II, blastocyst diameters $(\mu \mathrm{m})$ after the various treatments were (mean \pm S.E.): Treatment $1,140 \pm 1 \cdot 0$; Treatment 2, $140 \pm 1.0$; Treatment 3, $1030 \pm 20$; Treatment 4, $820 \pm 20$; Treatment 5, 910 \pm 20 . No effect of storage for $24 \mathrm{hr}$ at $10^{\circ} \mathrm{C}$ on blastocyst expansion in vitro was noted (Treatments 1 and 2). Blastocyst size was much greater, however, for embryos grown in vivo (Treatments 3 to 5$)$ than for embryos developing in vitro $(P<0 \cdot 005)$. Embryos which became blastocysts in culture after storage (Treatment 4 ) and those collected as blastocysts from does (Treatment 5) were smaller $(P<0.05)$ than embryos transferred immediately after collection (Treatment 3 ).

Under the conditions of these experiments, a smaller proportion of stored rabbit embryos developed into blastocysts in vitro than in vivo, and the latter were many times larger than the former. Embryos transferred immediately (Treatment 3) had blastocyst diameters similar to the mean of $1070 \mu \mathrm{m}$ reported by Adams (1958) for blastocysts collected $120 \mathrm{hr}$ post coitum. Storage for $24 \mathrm{hr}$ at $10^{\circ} \mathrm{C}$ followed by subsequent development in vivo (Treatment 4) and continuous development for $120 \mathrm{hr}$ in females which had superovulated (Treatment 5) resulted in blastocysts with smaller diameters $(P<0.05)$. This finding concerning superovulation is not in agreement with results of Hafez \& Rajakoski (1964) and Adams (1965), but these workers measured fewer blastocysts and blastocysts of a different age.

In our studies superovulation may have altered the postovulatory hormonal or uterine environment, as preovulatory injections of progesterone have been found to inhibit blastocyst growth and expansion (Allen \& Foote, 1973).

The authors thank Marilee Allen, Linda Pierro and Michael Simkin for help 
with various aspects of this project. The research was supported in part by NIH Research Grant HD 03471.

\section{REFERENCES}

AdAms, C.E. (1958) Egg development in the rabbit. The influence of post-coital ligation of the uterine tube and of ovariectomy. F. Endocr. 16, 283-294.

ADAMs, C.E. (1965) Influence of maternal environment on preimplantation stages of pregnancy in the rabbit. In Preimplantation Stages of Pregnancy, pp. 345-373. Ed. G. E. W. Wolstenholme. Little, Brown and Company, Boston.

ALLEN, M.C. \& Foote, R.H. (1973) The effect of progesterone on the early development of the rabbit embryo. Fert. Steril. 24, 220-226.

Anderson, G.B. \& Foote, R.H. (1974) Effects of low temperature storage upon subsequent energy metabolism of rabbit embryos. Expl Cell Res. 87, 302-306.

ANDERson, G.B. \& Foote, R.H. (1975a) Effects of low temperature upon subsequent nucleic acid and protein synthesis of rabbit embryos. Expl Cell Res. 90, 73-78.

Anderson, G.B. \& Foote, R.H. (1975b) Development of rabbit embryos after storage at $10^{\circ} \mathrm{C}$. F. Anim . Sci. 40, 900-904.

Bank, H. \& Maurer, R.R. (1974) Survival of frozen rabbit embryos. Expl Cell Res. 89, 188-196.

CHANG, M.C. (1947) Normal development of fertilized rabbit ova stored at low temperature for several days. Nature, Lond. 159, 602-604.

Hafez, E.S.E. \& Rajakoski, E. (1964) Growth and survival of blastocysts in the domestic rabbit. I. Effect of maternal factors. $\mathcal{7}$. Reprod. Fert. 7, 229-240.

KANE, M.T. \& Foote, R.H. (1970) Culture of two- and four-celled rabbit embryos to the expanding blastocyst stage in synthetic media. Proc. Soc. exp. Biol. Med. 133, 921-925.

Kardymowicz, O. (1972) Successful in vitro storage of fertilized sheep ova for 10 days. Proc. 7th Int. Congr. Anim. Reprod. \& A.I., Munich 1, 500-503.

KeNNELLY, J.J. \& FoOTE, R.H. (1965) Superovulatory responses of pre- and post-pubertal rabbits to commercially available gonadotrophins. F. Reprod. Fert. 9, 177-188.

Moore, N.W. \& Bilton, R.J. (1973) Storage of fertilized sheep ova at $5^{\circ}$ C. Aust. F. biol. Sci. 26, $1421-1426$.

Sreenan, S.J., Scanlon, P. \& Gordon, I. (1970) Storage of fertilized cattle ova in vitro. F. agric. Sci., Camb. 74, 593-594.

Steel, R.G.D. \& Torrie, J.H. (1960) Principles and Procedures of Statistics. McGraw-Hill, New York.

WhITTINGHAM, D.G. \& WhitTEN, W.K. (1974) Long-term storage and aerial transport of frozen mouse embryos. F. Reprod. Fert. 36, 433-435.

WiLMuT, I. \& Rowson, L.E.A. (1973) Experiments on the low temperature preservation of cow embryos. Vet. Rec. 92, 686-690. 